\title{
High-altitude hypoxia. A challenging strain targeting cellular redox homeostasis
}

\author{
José Magalhães 1,2
}

António Ascensão ${ }^{1,2}$

https://doi.org/10.5628/rpcd.08.03.459

\author{
${ }^{1}$ Research Centre in Physical Activity, Health and Leisure \\ University of Porto \\ Portugal \\ ${ }^{2}$ Department of Sport Biology \\ Faculty of Sport \\ University of Porto \\ Portugal
}

\begin{abstract}
After putting forward some evidence of hypobaric hypoxia as a particular stimulus causing systemic, tissue and cellular challenging strains, the present short review is focused on the current findings relating the reasoning of increased tissue generation of reactive oxygen and nitrogen species (RONS) when humans and animals organisms are exposed to high-altitude environments. In contrast to earlier concepts, hypobaric hypoxia-induced decreased physiological oxygen availability seems to be a prompt condition to cellular loss of redox homeostasis resulting in increased oxidative stress, which does not further augment upon reoxygenation. The apparently paradoxical condition of hypoxia-induced free radical production is regulated by very particular and specific cellular mechanisms, being mitochondria special sources and targets of RONS as well as critical organelles related to cellular death mediated by apoptosis.
\end{abstract}

Key-words: hypoxia, free radicals, oxidative damage, mitochondria, apoptosis

\section{RESUMO}

Hipóxia de altitude.

Um estímulo indutor de alterações na homeostasia redox

Após considerar evidências da hipoxia hipobárica enquanto um estímulo particular indutor de alterações deletérias a nível sistémico, tecidual e celular, a presente breve revisão focar-se-á sobre os principais mecanismos associados à produção adicional de espécies reactivas de oxigénio $e$ nitrogénio (ERON) em humanos e animais submetidos a condições ambientais de hipóxia. Em oposição aos conceitos pioneiros, a diminuição da disponibilidade de oxigénio que se verifica em condições de hipoxia hipobárica é uma condição favorável à perda da homeostasia redox celular resultando num incremento do stress oxidativo, o qual não é agravado após períodos de reoxigenação. Esta aparente condiçãa paradoxal de geração adicional de radicais livres é regulada por mecanismos celulares específicos, sendo as mitocôndrias fontes e simultaneamente alvos das ERON, bem como organelos críticos associados à morte celular mediada por apoptose.

Palavras-chave: hipoxia, radicais livres, lesão oxidativa, mitocôndrias, apoptose 


\section{INTRODUCTION}

Oxygen deprivation, usually known as hypoxia is a constant threat to the animal kingdom. Acute or chronic exposure to conditions of high-altitude hypoxia has been considered an important challenge for the organism compromising body functioning, including cardiorespiratory, endocrine, metabolic, nutritional and thermal homeostasis $(14,38,41,46,47,56$, $79,94,103,113)$. In the last years, evidence of systemic and local oxidative stress and damage, resulting from a wide imbalance between oxidant production and the antioxidant capacity, has also been reported during and after hypoxia exposure. Actually, under several distinct set up conditions conducted with humans and animals, data have revealed increased free radical production and signs of oxidative damage to lipids, proteins and DNA in several tissues. The present short review focuses on the effects of hypoxia on free radical production and on related disturbances of redox homeostasis. The impact of reoxygenation upon hypoxia, the main mechanisms behind RONS production in oxygen-deprived environments with particular emphasis on mitochondria both as source and target of free radical as well as the role of acclimatization on hypoxia-related oxidative deleterious effects will also be discussed.

\section{HYPOBARIC HYPOXIA.}

\section{A GREAT SYSTEMIC AND TISSUE CHALLENGE}

High-altitude exposure has been considered an important challenging strain for the organism compromising the homeostasis of several physiological features such as cardiorespiratory, endocrine, metabolic, nutritional and thermal(14, 38, 41, 46, 47, 56, 79, 94, 103, 113). Actually, in addition to hypoxia associated with the low barometric pressure, distinct environmental stimuli are also imposed by high-altitude, including extreme cold, temperature shifts, very low absolute humidity, increased ultraviolet radiation, lead to an exacerbated physiological stress $(6,51,113,116)$.

Barometric pressure decreases in an inverse proportion to altitude(117) resulting in the decrease of the partial pressure of inspired oxygen, which affects the "oxygen cascade" and diminishes oxygen diffusion capacity from the atmospheric air to the lungs, blood and tissues, i.e., inducing systemic and local oxygen deprivation $(51,95)$. Dioxygen molecule is vital for mammalian cells serving as the ending electron acceptor in the oxidative process that mediates energy generation in mitochondria. Therefore, to counteract the limit oxygen availability, a compensatory fine tuning of the hypoxia sensing and signal transduction pathways eliciting central respiratory, circulatory and several peripheral processes is triggered $(45,46)$. However, depending on the severity, the duration and the rapidity of the onset of hypoxia, the decreased levels of oxygen might severely compromise body metabolism promoting reversible or irreversible loss of tissue and cell homeostasis and leading to organic and functional decay. Given that even the acclimatized body remains hypoxic at certain severe altitudes ${ }^{(118)}$, an organic deterioration is a condition that is often described in animals and humans after some time spent at severe high-altitude $(13,113,125)$. This deleterious organic phenomenon is frequently attributed to distinct factors usually experienced by dwellers in high-altitude sojourns, such as dehydration, starvation, physical exhaustion and extreme cold(118). However, it seems that oxygen unavailability per se, if sufficiently severe, brisk or prolonged, plays a major role causing mental and physical deterioration. In fact, hypoxia exposure seems to result in significant weight loss, skeletal muscle degradation, poor appetite, slow recovery from fatigue, lethargy, irritability, an increasing lack of willpower to start new tasks $(1,15,17,30,50,80,119)$, and, ultimately, in a benign illness related to neurological and respiratory symptoms that might result in high-altitude cerebral ${ }^{(41)}$ or pulmonary edema(12). Nevertheless, despite the scientific worldwide efforts to find out and better understand the specific mechanisms underlying these hypoxia-mediated deterioration occurrences, there are still many doubts and unanswered questions.

\section{REDOX CHANGES INDUCED BY HYPOXIA \\ - INCREASED OXIDATIVE STRESS AND DAMAGE}

Amongst many potential biological mechanisms suggested to explain the different physiological constrains associated with high-altitude exposure, increased cellular oxidative stress has been reported during the last years. In fact, high-altitude hypoxia has been associated with enhanced generation of reactive oxygen and nitrogen-based species (RONS) 
in both animals and humans. Probably linked to an increased production of RONS and to an inability of the antioxidant systems to counteract RONS effects, evidence of lipid peroxidation, protein oxidation and oxidative DNA damage have been described in humans exposed to altitude environments $(7,66,77,87)$. It is important to note that in high-altitude other factors besides hypoxia, such as intense UV radiation, brisk air temperature variations and physical activity may also be related to RONS formation leading to enhanced oxidative stress ${ }^{(105)}$. For example, physical activity, such as that associated to mountaineering itself, could be an exacerbating factor of the oxidative stress and damage observed in many climbers and high-altitude dwellers.

Attempting to emphasize the role of hypoxia, a number of acute, chronic and intermittent hypoxia studies with $\operatorname{rats}^{(22,97,106)}$ and humans $(7,9,54)$ have been conducted in both hypobaric and normobaric conditions confirming high-altitude hypoxia per se as an independent modulator of cell and tissue redox status. Data from Magalhães and co-workers in humans and rats, both in plasma ${ }^{(69,73)}$ and skeletal muscle (70-72), are consistent with others reporting increased oxidative damage and an inability of the antioxidant system to cope with the increased production of RONS under hypoxia( $7,23,52,54,66,77,89,98$, 106). Increased lipid peroxidation measured by thiobarbituric acid reactive substances (TBARS) or malondialdehyde (MDA), and enhanced protein oxidation estimated by carbonyl derivatives groups or sulfhydryl groups ( $\mathrm{SH}$ ) were found at distinct levels of cell organization (69-73). Moreover, DNA damage expressed as increased strand breaks and endonuclease III-sensitive sites was described in human skeletal muscle after 2 weeks of hypoxia(107).

This apparent physiological paradox was confirmed by in vivo direct measurements and in vitro assay of reactive oxygen species (ROS) production in different tissues and experimental conditions of hypoxia. Using electron paramagnetic resonance spectroscopy, Bailey et al.(10) identified a clear increase in blood and cerebral spinal fluid concentration of ROS in humans exposed for $18 \mathrm{~h}$ to $12 \%$ of oxygen.

Additionally, rats exposed to 10-min of normobaric hypoxia $\left(10 \% \mathrm{O}_{2}\right)$ revealed an increase in ROS- dependent dihydrorhodamine 123 fluorescence signal in mesenteric circulation by nearly $200 \%$ above control values (120). In isolated rat diaphragm strips loaded with dihydrofluorescein-DA, Zuo et al.(127) showed that the transition to low intracellular oxygen pressure prompt a burst of intracellular ROS. Vanden Hoek et al.(109) and Damerau et al.(28) also observed increased ROS production during hypoxia in cardiac myocytes. These data are consistent with earlier observations by Park et al.(84) using electron spin resonance (ESR) in intact hearts during ischemia and Kevin et al.(58) using redox sensitive fluorescent probes in the intact heart. Moreover, Duranteau et al.(33) showed that the extent of increase in dichlorofluorescin fluorescence in cardiomyocytes was proportional to the severity of hypoxia. These responses were attenuated by inhibitors that block the generation of ubiquinol at mitochondrial complex I and II, which suggest that hypoxia increases ROS production at complex III of mitochondrial electron transport chain.

In accordance, data from distinct studies dealing with antioxidants in humans $(8,23,87,102)$ and rats $(52$, $70,97,98)$ submitted to hypoxia clearly demonstrated benefits of such supplementation against oxidative stress and damage. Additionally, RONS produced in skeletal muscle during hypoxia contribute to decreased force production and both intracellular and extracellular antioxidants markedly attenuated the decline and loss of contractile function observed during hypoxia ${ }^{(76,122)}$.

Similar to other studies dealing with systemic(reviewed in 31,67$)$ or local $(78,88,109)$ hypoxic or anoxic pathophysiological states, one can argue that hypoxia truly engenders a biological paradox, i.e., too less molecules of stable oxygen seem to generate more molecules of unstable and reactive oxygen with systemic and tissue deleterious consequences to organism. Therefore, although the use of oxygen as metabolic fuel allows a vital and attractive harvest of energyrich phosphates per molecule of glucose, aminoacids or fatty acids, it seems that in oxygen depressed environments, such as high-altitude, a significant fraction of the oxygen utilized by the body undergoes a univalent reduction, resulting in the formation of $\operatorname{RONS}(6,11)$. 


\section{SUB-CELLULAR SITES AND MECHANISMS OF FREE RADICAL GENERATION IN HYPOXIC TISSUES}

Despite the considerations on hypoxia-induced oxidative stress and damage, many important questions concerning the possible mechanisms involved in this exceeded production of RONS under hypoxia remain to be adequately addressed. Currently, work on this research topic suggests that some of the mechanisms able to explain, at least in part, the increased RONS production in humans and rats submitted to hypoxia are: (i) a rapid microvascular inflammatory response resulting in increased formation of the pro-inflammatory mediator leukotriene B4 and in leukocyte endothelium adherence and migration into perivascular space via nitric oxide depletion $(107,120,121)$; (ii) the increased xanthine oxidase activity, resulting from cellular energetic and metabolic inefficiency and excessive calcium levels ${ }^{(49)}$; (iii) the increased spontaneous epinephrine oxidation $^{(2,55)}$; (iv) the enhanced nitric oxide (NO) production stimulated by elevated levels of cytosolic calcium ${ }^{(42)}$ or by increased activity of constitutive NO synthase(123) occurring during hypoxia, and (v) the accumulation of reduced equivalents in the electron transport chain (ETC) - the so-called condition of reductive stress $(33,57)$.

Despite the relevance of all the other above-mentioned mechanisms, this section will focus in particular on mitochondria as a RONS source and target during hypoxic conditions.

Mitochondria produce the energy required to drive the endergonic and vital biochemical processes of cell life through a rather well-coupled mechanism of oxidative phosphorylation(16). Additionally, mitochondria are also critical organelles in the modulation of cellular osmotic regulation, redox status and $\mathrm{pH}$ control, signal transduction, and in the establishment of cellular calcium homeostasis(112).

Nonetheless, mitochondria respiratory function has been considered a relevant mechanism involved in cellular ROS production under conditions of oxygen deprivation $(64,85,108)$. In such hypoxic conditions, reducing equivalents seem to accumulate throughout the mitochondria ETC due to an inefficacy to transport electrons to oxygen. Actually, a hypoxiainduced decrease in $V_{\max }$ of cytochrome $c$ oxidase seems to favour an increase in the reductive state of mitochondrial electron carriers upstream of cytochrome $a a_{3}{ }^{(33)}$ favoring electron leakage and increased univalent reduction of oxygen with formation of $\operatorname{ROS}(20,29,33,57,76,100)$. Nevertheless, cytochrome $c$ oxidase can hardly be considered as a prompt oxygen sensor under hypoxic conditions. Cytochrome $c$ oxidase in rat hepatocytes required 90-120 min under hypoxia to undergo a decrease in $V \max ^{(19)}$, yet data from Chandel et al.(21) revealed that cells displayed hypoxia-inducible factor-1alpha (HIF-1a) protein accumulation, a key regulator of transcriptional responses to hypoxia, within $30 \mathrm{~min}$. Based on the difference between the duration of hypoxia needed to elicit alterations in cytochrome $c$ oxidase $V \max$ and the time required to stabilize HIF-1a, it is not credible that cytochrome $c$ oxidase could serve as the primary oxygen sensor in hypoxia. Rather, it appears that mitochondrial complex III must possess inherent sensitivity to distinct oxygen concentrations allowing it to adjust its generation of ROS inversely with the oxygen tension $(21,39)$. In fact, mediated by some hypothetical mechanisms that ultimately increase the transfer of an electron from the ubisemiquinone to molecular oxygen, complex III seems to be the primary site of ROS production during hypoxia, and a competent cellular oxygen sensor (for review see 40).

Depending on the severity and the duration of the hypoxia conditions, mitochondria themselves may also become targets from ROS resulting in the peroxidation of membrane lipids, protein oxidation and DNA cleavage $(25,61,86)$, which can culminate in the down-regulation of the respiratory function $(59,90,115)$, impaired ATP synthesis (5) and, eventually, in cellular death $(24,53,59)$. Data from Magalhães and coworkers ${ }^{(70)}$ support the role of skeletal muscle mitochondria as a potential ROS source and as an oxidative target organelle under severe but physiological hypoxic conditions. In mice exposed to $48 \mathrm{~h}$ of severe hypoxia equivalent to an altitude of $8500 \mathrm{~m}$, skeletal muscle mitochondria significantly increased superoxide radical production and protein oxidation. The activity of the superoxide-sensitive enzyme aconitase significantly dropped by approximately $30 \%$ in animals exposed to simulate high-altitude when compared to control. Moreover, vitamin E supplementation protected mitochondria from both the over-pro- 
duction of carbonyl groups and aconitase inactivation induced by hypoxia. These results were consistent with data obtained elsewhere confirming the role of mitochondria as an important ROS source(64, $65,108)$ and target $(83,124)$ under hypoxic conditions.

\section{HYPOXIA-INDUCED MITOCHONDRIAL DYSFUNCTION AND INCREASES THE LEVELS OF APOPTOSIS}

Under severe conditions of hypoxia, the oxidativemediated mitochondrial dysfunction may contribute, at least partially, to some of the described skeletal muscle morphological changes (for review see 18, 48), including mitochondrial swelling, cristae degeneration and relevant accumulation of lipofuscin-like pigments $(3,68,75)$, which have also been described in several other tissues $(62,96,99)$ as being related to abnormal mitochondrial functionality and to cellular death fate. Some studies reported that under conditions of oxidative stress and increased cytosolic free calcium, mitochondria function can become severely affected(reviewed in 27). In fact, decreased activity of some of the ETC protein complexes and/or citric acid-cycle enzymes ${ }^{(124)}$, and inner membrane phosphoslipid peroxidation, including cardiolipin(81, 82) mediated by free radical oxidation seems to correlate well with depressed mitochondrial function. In accordance, hypoxia-induced oxidative stress significantly impaired mitochondrial respiration as demonstrated by decreased state 3 , respiratory control ratio and ADP/O, and by increased state 4 with both complex I and II-linked substrates(70), which contributed to decreased mitochondrial phosphorylation efficiency and coupling between respiration and ATP synthesis. These assumptions were confirmed by the decreased respiratory rate in the presence of the uncoupler CCCP (carbonyl cyanide m-chlorophenylhydrazone) and by increased respiration in the presence of the ATP synthase inhibitor oligomycin. Vitamin E supplementation was able to attenuate most of the mitochondrial functional changes induced by hypoxia, which further supports the oxidative nature of mitochondrial dysfunction. Moreover, depending on the magnitude of the insult, alterations in mitochondrial membrane permeability mediated by distinct aetiologies may predispose to the activation of the intrinsic pathway of apoptotic cell death. In fact, the dysfunction of the adenine nucleotide translocases $(44,110)$ and/or the opening of the mitochondrial permeability transition pore (mPTP) (for refs see 26, 44, 60) might result in important bioenergetic consequences, namely (i) the loss of mitochondrial transmembrane potential, (ii) the uncoupling of the respiratory chain, (iii) the increased production of the superoxide radical, (iv) the disturbance of mitochondrial biogenesis, (v) the outflow of matrix calcium and glutathione, (vi) the release of soluble intermembrane proteins, and (vii) a burst of mitochondrial oxygen consumption, among other effects. Eventually, this scenario of mitochondrial dysfunction might entail a bioenergetic collapse that can culminate in the disruption of plasma membrane integrity (necrosis) and/or in the activation of specific cysteine apoptogenic proteases (caspases) that trigger the mitochondrial intrinsic pathway of apoptosis (for review see 43, 63). In accordance, prolonged simulated conditions of high-altitude decreased inner and outer mice skeletal muscle mitochondrial membrane integrity and increased $\mathrm{Bax} / \mathrm{Bcl}-2$ ratio suggesting that severe and persistent hypobaric hypoxia exposure predisposes skeletal muscle to cell death ${ }^{(74)}$. In clear contrast, Riva and coworkers ${ }^{(92)}$ showed an over-expression of Bax and $\mathrm{Bcl}-2$ in skeletal muscle of young rats growing under moderate chronic hypoxia conditions $\left(10 \% \mathrm{O}_{2}\right)$. In this case, the graduate and less severe level of hypoxia exposure was translated into an increase of the Bcl-2/Bax ratio allowing a better protection against apoptosis. In fact, no sign of apoptosis was detected by TUNEL, annexin V-binding and DNA electrophoresis analysis. However, the protective effect of the acclimatization process against skeletal muscle oxidative stress already demonstrated elsewhere $(71)$ and/or the hypoxia severity might probably explain, at least in part, this discrepancy in the results. In fact, recent data from molecular analysis brought by Schroff and Chandel(104) suggest that the outcome of the mixed signals generated by hypoxia is determined by the level of the hypoxic stimulus. The authors described a pathway whereby severe but not moderate hypoxia promotes apoptosis. The antiapoptotic gene Mcl-1 is induced by hypoxia through HIF-1; however, under severe hypoxia, Mcl-1 is targeted for degradation by the proteasome, whereas under mild hypoxia remains elevated favoring sur- 
vival. Nonetheless, mitochondria isolated from ventricular myocytes of rats exposed to intermittent hypoxia (6h/day at $5000 \mathrm{~m}$ for 42 days) seem to be more resistant to the opening of the MPTP and to cytochrome $c$ release after reperfusion injury(126). Enhancement of the mitochondrial tolerance against calcium overload, most likely through the activation of mitochondrial ATP-sensitive potassium channels, might underlie the protective mechanism of intermittent hypoxia on cardiomyocytes submitted to reperfusion injury.

Unfortunately, studies concerning the influence of less severe hypoxic conditions, equivalent to those that many humans face around the world, on muscle mitochondrial function are still missing.

Nevertheless, data regarding the impact of such hypoxic conditions on whole muscle tissue, blood or plasma oxidative stress and damage markers suggest that less intense alterations would probably occur at mitochondrial level(74).

\section{DOES REOXYGENATION UPON HYPOXIA CAUSES FURT- HER INCREASE IN OXIDATIVE STRESS AND DAMAGE?}

The injury perpetrated by the mechanism of ischemia/reperfusion is perhaps the supreme example of pathologic atavism in which intracellular RONS production exceeds the cellular defenses and can trigger massive stress and damage to the affected cells ${ }^{(114)}$. In fact, while RONS may be generated in a smaller extent during the ischemic period, far greatest production of these compounds occurs after reintroduction of oxygen during the period of reperfusion $(34,36,111)$. Accordingly, ultrastructural and metabolic cellular disturbances related with the decreased oxygen availability during ischemia and aggravated oxidative-mediated tissue harmful effects during the reperfusion period have been reported in several tissues $(34,36,111)$. In fact, enhanced capillary permeability, endothelial ROS production, and polymorphonuclear leukocytes mobilization with endothelial adherence and tissue infiltration have been described in post-ischemic reperfused tissues ${ }^{4}$, $32,101)$.

However, despite evidence demonstrating that systemic physiological hypoxia induced by real or simulated high-altitude exposure exacerbate cellular RONS production and oxidative stress, some studies also demonstrate that, in contrast with to the model of ischemia/reperfusion(for review see 35), the levels of RONS production ${ }^{(120)}$ and oxidative stress and damage $(54,73)$ do not increase further during or after the reoxygenation period subsequent to hypoxia. A report from Magalhães and coworkers(73) revealed that 4 hours of simulated high-altitude exposure equivalent to $5500 \mathrm{~m}$ significantly increased the burden of oxidative stress during the hypoxic period in humans; nevertheless, no additional signs of oxidative stress or damage were observed at the end of the pressurization/reoxygenation period. In fact, increased levels of protein and lipid oxidation, as well as reduced total antioxidant capacity were observed during the hypobaric hypoxia exposure, but no additional oxidative modifications were found after the reoxygenation period when compared with values obtained after the $4 \mathrm{~h}$ of hypobaric hypoxia. In conformity with this findings, data from a study in which 8 male subjects were continuous and gradually exposed for 31 days to a simulated Everest ascend in a hypobaric chamber and re-pressurized in 2 days until sea level conditions (Operation Everest III-Comex'97) revealed that the conditions of oxidative stress and damage observed during the hypoxic period were not exacerbated after reoxygenation(54). Moreover, in a study with rats submitted to 10-min in-vivo normobaric hypoxia $\left(10 \% \mathrm{O}_{2}\right)$ followed by a 10 -min normoxic $\left(21 \% \mathrm{O}_{2}\right)$ recovery period, Wood and coworkers ${ }^{(120)}$ showed an increase in ROS-dependent dihydrorhodamine 123 fluorescence signal in mesenteric circulation by nearly $200 \%$ above control values during hypoxia, which did not further increase, instead it progressively decreased towards control, during the recovery room air breathing period. Consistently, a report from Risom and coworkers ${ }^{(91)}$ also demonstrated that the levels of DNA strand breaks and oxidatively damaged purine bases in human mononuclear blood cells significantly increased after $2 \mathrm{~h}$ of hypoxia corresponding to $5500 \mathrm{~m}$ above sea level, but did not further increase after $2 \mathrm{~h}$ of reoxygenation. All together, these data suggest fundamental differences in the underlying mechanisms responsible for redox status disturbances in humans and rats during conditions of physiological hypoxia-reoxygenation vs. the classical model of ischemia/reperfusion. 
Actually, in clear contrast with studies dealing with ischemia/reperfusion (for review see 34, 93, 111), in which oxidative stress and cellular injury are severely aggravated during reperfusion, data suggest that the reoxygenation period does not further increase the levels of oxidative stress and damage induced by the previous hypoxic period. Nevertheless, data from Gonzalez and coworkers(37) demonstrated that, in contrast with previous reports expressed above, humans exposed during 3 days to an altitude of $3500 \mathrm{~m}$ revealed enhanced erythrocyte membrane oxidative damage one day upon returning to sea level when compared to values obtain at altitude. Discrepancies in the timing of data collection upon returning to sea level conditions, tissue susceptibility and the sensitivity of the different techniques are possible explanations for these differences.

Additional studies are required to clarify this important topic. Moreover, no data has been published regarding the impact of this phenomenon on skeletal muscle. Considering the heterogeneity of response of distinct tissues to the same insult and the fact that skeletal muscle has been considered very resistant to ischemia/reperfusion, additional studies should address the impact of hypoxia/reoxygenation in this tissue.

\section{CONCLUSION}

Despite being an apparent paradox, accumulating evidence demonstrate that oxygen deprived environments favour increased RONS generation and the occurrence of enhanced cellular oxidative stress. Data obtained in distinct experimental settings, models and tissues, including skeletal muscle, have reported unequivocal clues of RONS production by distinct cellular sources, including by mitochondria with consequent signs of oxidative macromolecular damage of lipids, proteins and DNA. Nevertheless, moderate hypoxia-induced RONS may be an adaptive cellular reaction to the disproportion between oxygen supply and demand, and play a yet incompletely defined role in the physiological response to hypoxia. As an example, mitochondria are currently considered determinant cellular hypoxic-oxygen sensors contributing with RONS for cellular adaptation depending on important redox-dependent signaling mechanisms. On the other hand, under severe hypoxic conditions, tissues may fail to maintain a normal redox homeostasis, which might result in cell dysfunction and, ultimately, in the activation of cell death pathways.

\section{ACKNOWLEDGEMENTS}

António Ascensão (SFRH/BPD/42525/2007) is supported by a grant from the Portuguese Foundation for Science and Technology.

\section{CORRESPONDING AUTHOR}

José Magalhães

Research Center in Physical Activity,

Health and Leisure

Department of Sport Biology

Faculty of Sport Sciences,

University of Porto

R. Dr. Plácido Costa, 91

4200-450 Porto

Portugal

Phone: 00-351-22-5074774

Fax: 00-351-225500689

E-mail: jmaga@fade.up.pt 


\section{REFERENCES}

1. Abraini JH, Bouquet C, Joulia F, Nicolas M, Kriem B (1998). Cognitive performance during a simulated climb of mount everest: implications for brain function and central adaptive processes under chronic hypoxic stress. Pflugers Arch 436:553-559

2. Alessio H (2000). Lipid peroxidation in healthy and diseased models: influence of different types of exercise. In: Sen CK, Packer L, Hanninen O (eds) Handbook of oxidants and antioxidants in exercise. Elsevier science B.V., Basel, p 115-127

3. Amicarelli F, Ragnelli AM, Aimola P, Bonfigli A, Colafarina S, Di Ilio C, Miranda M (1999). Age-dependent ultrastructural alterations and biochemical response of rat skeletal muscle after hypoxic or hyperoxic treatments. Biochim Biophys Acta 1453:105-114

4. Appell HJ, Duarte JA, Gloser S, Remiao F, Carvalho F, Bastos ML, Soares JM (1997). Administration of tourniquet. II. Prevention of postischemic oxidative stress can reduce muscle edema. Arch Orthop Trauma Surg 116:101105

5. Arai M, Imai H, Koumura T, Yoshida M, Emoto K, Umeda M, Chiba N, Nakagawa Y (1999). Mitochondrial phospholipid hydroperoxide glutathione peroxidase plays a major role in preventing oxidative injury to cells. J Biol Chem 274:4924-4933

6. Askew EW (2002). Work at high altitude and oxidative stress: antioxidant nutrients. Toxicology 180:107-119

7. Bailey D, Davies B, Davison G, Young I (2000). Oxidatively stressed out at high-altitude! International Society for Mountain Medicine Newsletter 10:3-13

8. Bailey DM, Davies B (2001). Acute mountain sickness; prophylactic benefits of antioxidant vitamin supplementation at high altitude. High Alt Med Biol 2:21-29

9. Bailey DM, Davies B, Young IS (2000). Evidence for reactive oxidant generation during acute physical exercise and normobaric hypoxia in man. J Physiol 528P:99P

10. Bailey DM, Roukens R, Knauth M, Kallenberg K, Christ S, Mohr A, Genius J, Storch-Hagenlocher B, Meisel F,

McEneny J, Young IS, Steiner T, Hess K, Bartsch P (2005). Free radical-mediated damage to barrier function is not associated with altered brain morphology in high-altitude headache. J Cereb Blood Flow Metab 26(1): 99-111

11. Bakonyi T, Radak Z (2004). High altitude and free radicals. J Sports Sci Med 3:64-69

12. Bartsch P (1999). High altitude pulmonary edema. Med Sci Sports Exerc 31:S23-27

13. Bigard AX, Douce P, Merino D, Lienhard F, Guezennec CY (1996). Changes in dietary protein intake fail to prevent decrease in muscle growth induced by severe hypoxia in rats. J Appl Physiol 80:208-215

14. Bonnon M, Noel-Jorand MC, Therme P (2000). Effects of different stay durations on attentional performance during two mountain expeditions. Aviat Space Environ Med 71:678684

15. Bouquet C, Gardette B, Gortan C, Therme P, Abraini JH (2000). Color discrimination under chronic hypoxic conditions (simulated climb "Everest-Comex 97"). Percept Mot Skills 90:169-179

16. Cadenas E (2004). Mitochondrial free radical production and cell signaling. Mol Aspects Med 25:17-26

17. Caquelard F, Burnet H, Tagliarini F, Cauchy E, Richalet JP,
Jammes Y (2000). Effects of prolonged hypobaric hypoxia on human skeletal muscle function and electromyographic events. Clin Sci (Colch) 98:329-337

18. Cerretelli P, Hoppeler H (1996). Morphologic and metabolic response to chronic hypoxia: The muscle system. In: Fregly M, Blatteis C (eds) Handbook of Physiology. Section 4: Environmental Physiology. Oxford University Press, New York, p 1155-1182

19. Chandel NS, Budinger GR, Choe SH, Schumacker PT (1997). Cellular respiration during hypoxia. Role of cytochrome oxidase as the oxygen sensor in hepatocytes. $J$ Biol Chem 272:18808-18816

20. Chandel NS, Maltepe E, Goldwasser E, Mathieu CE, Simon MC, Schumacker PT (1998). Mitochondrial reactive oxygen species trigger hypoxia-induced transcription. Proc Natl Acad Sci U S A 95:11715-11720

21. Chandel NS, McClintock DS, Feliciano CE, Wood TM, Melendez JA, Rodriguez AM, Schumacker PT (2000). Reactive oxygen species generated at mitochondrial complex III stabilize hypoxia-inducible factor-1alpha during hypoxia: a mechanism of $\mathrm{O} 2$ sensing. J Biol Chem 275:25130-25138

22. Chang SW, Stelzner TJ, Weil JV, Voelkel NF (1989). Hypoxia increases plasma glutathione disulfide in rats. Lung 167:269-276

23. Chao WH, Askew EW, Roberts DE, Wood SM, Perkins JB (1999). Oxidative stress in humans during work at moderate altitude. J Nutr 129:2009-2012

24. Childs AC, Phaneuf SL, Dirks AJ, Phillips T, Leeuwenburgh C (2002). Doxorubicin treatment in vivo causes cytochrome $\mathrm{C}$ release and cardiomyocyte apoptosis, as well as increased mitochondrial efficiency, superoxide dismutase activity, and Bcl-2:Bax ratio. Cancer Res 62:45924598

25. Choksi KB, Boylston WH, Rabek JP, Widger WR Papaconstantinou J (2004). Oxidatively damaged proteins of heart mitochondrial electron transport complexes. Biochim Biophys Acta 1688:95-101

26. Crompton M (1999). The mitochondrial permeability transition pore and its role in cell death. Biochem $J 341$ ( Pt 2):233-249

27. Crompton M (2004). Mitochondria and aging: a role for the permeability transition? Aging Cell 3:3-6

28. Damerau W, Ibel J, Thurich T, Assadnazari H, Zimmer G (1993). Generation of free radicals in Langendorff and working hearts during normoxia, hypoxia, and reoxygenation. Basic Res Cardiol 88:141-149

29. Dawson TL, Gores GJ, Nieminen AL, Herman B, Lemasters JJ (1993). Mitochondria as a source of reactive oxygen species during reductive stress in rat hepatocytes. Am J Physiol 264:C961-967

30. de Glisezinski I, Crampes F, Harant I, Havlik P, Gardette B, Jammes Y, Souberbielle JC, Richalet JP, Riviere D (1999). Decrease of subcutaneous adipose tissue lipolysis after exposure to hypoxia during a simulated ascent of $\mathrm{Mt}$ Everest. Pflugers Arch 439:134-140

31. Dekhuijzen PN (2004). Antioxidant properties of N-acetylcysteine: their relevance in relation to chronic obstructive pulmonary disease. Eur Respir J 23:629-636

32. Duarte JA, Gloser S, Remiao F, Carvalho F, Bastos ML, Soares JM, Appell HJ (1997). Administration of tourniquet. I. Are edema and oxidative stress related to each 
other and to the duration of ischemia in reperfused skeletal muscle? Arch Orthop Trauma Surg 116:97-100

33. Duranteau J, Chandel NS, Kulisz A, Shao Z, Schumacker PT (1998). Intracellular signaling by reactive oxygen species during hypoxia in cardiomyocytes. J Biol Chem 273:11619-11624

34. Ferrari R (1995) Metabolic disturbances during myocardial ischemia and reperfusion. Am J Cardiol 76:17B-24B

35. Ferrari R, Guardigli G, Mele D, Percoco GF, Ceconi C, Curello S (2004). Oxidative stress during myocardial ischaemia and heart failure. Curr Pharm Des 10:1699-1711

36. Franko J, Pomfy M, Novakova B, Benes L (1999). Stobadine protects against ischemia-reperfusion induced morphological alterations of cerebral microcirculation in dogs. Life Sci 65:1963-1967

37. Gonzalez G, Celedon G, Escobar M, Sotomayor C, Ferrer V, Benitez D, Behn C (2005). Red cell membrane lipid changes at 3,500 m and on return to sea level. High Alt Med Biol 6:320-326

38. Grissom CK, Elstad MR (1999). The pathophysiology of high altitude pulmonary edema. Wilderness Environ Med 10:88-92

39. Guzy RD, Hoyos B, Robin E, Chen H, Liu L, Mansfield KD, Simon MC, Hammerling U, Schumacker PT (2005). Mitochondrial complex III is required for hypoxia-induced ROS production and cellular oxygen sensing. Cell Metab 1:401-408

40. Guzy RD, Schumacker PT (2006). Oxygen sensing by mitochondria at complex III: the paradox of increased reactive oxygen species during hypoxia. Exp Physiol 91:807819

41. Hackett PH (1999). The cerebral etiology of high-altitude cerebral edema and acute mountain sickness. Wilderness Environ Med 10:97-109

42. Hampl V, Cornfield DN, Cowan NJ, Archer SL (1995). Hypoxia potentiates nitric oxide synthesis and transiently increases cytosolic calcium levels in pulmonary artery endothelial cells. Eur Respir J 8:515-522

43. Hengartner MO (2000). The biochemistry of apoptosis. Nature 407:770-776

44. Hirsch T, Marzo I, Kroemer G (1997). Role of the mitochondrial permeability transition pore in apoptosis. Biosci Rep 17:67-76

45. Hochachka PW, Rupert JL (2003). Fine tuning the HIF-1 'global' O2 sensor for hypobaric hypoxia in Andean highaltitude natives. Bioessays 25:515-519

46. Hochachka PW, Rupert JL, Monge C (1999). Adaptation and conservation of physiological systems in the evolution of human hypoxia tolerance. Comp Biochem Physiol A Mol Integr Physiol 124:1-17

47. Hoppeler H, Vogt M (2001). Muscle tissue adaptations to hypoxia. J Exp Biol 204:3133-3139

48. Hoppeler H, Vogt M, Weibel ER, Fluck M (2003). Response of skeletal muscle mitochondria to hypoxia. $\operatorname{Exp}$ Physiol 88:109-119

49. Hoshikawa Y, Ono S, Suzuki S, Tanita T, Chida M, Song C, Noda M, Tabata T, Voelkel NF, Fujimura S (2001). Generation of oxidative stress contributes to the development of pulmonary hypertension induced by hypoxia. $J$ Appl Physiol 90:1299-1306

50. Houston SC (1997). Operation Everest One and Two. Repiration 64:398-406
51. Hultgren H (1997). High Altitude Medicine. Stanford: Hultgren Publications

52. Ilavazhagan G, Bansal A, Prasad D, Thomas P, Sharma SK, Kain AK, Kumar D, Selvamurthy W (2001). Effect of vitamin E supplementation on hypoxia-induced oxidative damage in male albino rats. Aviat Space Environ Med 72:899-903

53. James AM, Murphy MP (2002). How mitochondrial damage affects cell function. J Biomed Sci 9:475-487

54. Joanny P, Steinberg J, Robach P, Richalet JP, Gortan C, Gardette B, Jammes Y (2001). Operation Everest III (Comex'97): the effect of simulated sever hypobaric hypoxia on lipid peroxidation and antioxidant defence systems in human blood at rest and after maximal exercise. Resuscitation 49:307-314

55. Jones D (1985). The role of oxygen concentration in oxidative stress: hypoxic and hyperoxic models. In: Sies $\mathrm{H}$ (ed) Oxidative Stress. Academic Press Inc, London, p 151195

56. karakucuk S, Mirza EG (2000). Ophtnalmological Effects of High Altitude. Ophthalmic Res 32:30-40

57. Kehrer JP, Lund LG (1994). Cellular reducing equivalents and oxidative stress. Free Radic Biol Med 17:65-75

58. Kevin LG, Camara AK, Riess ML, Novalija E, Stowe DF (2003). Ischemic preconditioning alters real-time measure of $\mathrm{O} 2$ radicals in intact hearts with ischemia and reperfusion. Am J Physiol Heart Circ Physiol 284:H566-574

59. Kokoszka JE, Coskun P, Esposito LA, Wallace DC (2001). Increased mitochondrial oxidative stress in the Sod2 (+/-) mouse results in the age-related decline of mitochondrial function culminating in increased apoptosis. Proc Natl Acad Sci U S A 98:2278-2283

60. Kokoszka JE, Waymire KG, Levy SE, Sligh JE, Cai J, Jones DP, MacGregor GR, Wallace DC (2004). The ADP/ATP translocator is not essential for the mitochondrial permeability transition pore. Nature 427:461-465

61. Kowaltowski AJ, Vercesi AE (1999). Mitochondrial damage induced by conditions of oxidative stress. Free Radic Biol Med 26:463-471

62. Kowaltowski AJ, Vercesi AE, Fiskum G (2000). Bcl-2 prevents mitochondrial permeability transition and cytochrome c release via maintenance of reduced pyridine nucleotides. Cell Death Differ 7:903-910

63. Kroemer G, Dallaporta B, Resche-Rigon M (1998). The mitochondrial death/life regulator in apoptosis and necrosis. Annu Rev Physiol 60:619-642

64. Kulisz A, Chen N, Chandel NS, Shao Z, Schumacker PT (2002). Mitochondrial ROS initiate phosphorylation of p38 MAP kinase during hypoxia in cardiomyocytes. Am J Physiol Lung Cell Mol Physiol 282:L1324-1329

65. Lemasters JJ, Nieminen AL (1997). Mitochondrial oxygen radical formation during reductive and oxidative stress to intact hepatocytes. Biosci Rep 17:281-291

66. Lundby C, Pilegaard H, van Hall G, Sander M, Calbet J, Loft S, Moller P (2003). Oxidative DNA damage and repair in skeletal muscle of humans exposed to high-altitude hypoxia. Toxicology 192:229-236

67. MacNee W (2000). Oxidants/antioxidants and COPD. Chest 117:303S-317S

68. Magalhaes J, Ascensao A, Amado F, Soares JM, Neuparth MJ, Ferreira R, Amado F, Duarte JA (2005). Skeletal muscle ultrastructural and plasma biochemical signs of 
ehdothelium dysfunction induced by a high-altitude expedition (Pumori, 7161m). Basic Appl Myol 15:29-35

69. Magalhaes J, Ascensao A, Marques F, Soares JM, Ferreira R, Neuparth MJ, Duarte JA (2005). Effect of a high-altitude expedition to a Himalayan peak (Pumori, 7,161 m) on plasma and erythrocyte antioxidant profile. Eur J Appl Physiol 93:726-732

70. Magalhaes J, Ascensao A, Soares JM, Ferreira R, Neuparth MJ, Marques F, Duarte JA (2005). Acute and severe hypobaric hypoxia increases oxidative stress and impairs mitochondrial function in mouse skeletal muscle. J Appl Physiol 99:1247-1253

71. Magalhaes J, Ascensao A, Soares JM, Ferreira R, Neuparth MJ, Oliveira J, Amado F, Marques F, Duarte JA (2005). Acute and chronic exposition of mice to severe hypoxia: the role of acclimatization against skeletal muscle oxidative stress. Int J Sports Med 26:102-109

72. Magalhaes J, Ascensao A, Soares JM, Neuparth MJ, Ferreira R, Oliveira J, Amado F, Duarte JA (2004). Acute and severe hypobaric hypoxia-induced muscle oxidative stress in mice: the role of glutathione against oxidative damage. Eur J Appl Physiol 91:185-191

73. Magalhaes J, Ascensao A, Viscor G, Soares J, Oliveira J, Marques F, Duarte J (2004). Oxidative stress in humans during and after 4 hours of hypoxia at a simulated altitude of $5500 \mathrm{~m}$. Aviat Space Environ Med 75:16-22

74. Magalhaes J, Ferreira R, Neuparth MJ, Oliveira PJ, Marques F, Ascensao A (2007). Vitamin E prevents hypobaric hypoxia-induced mitochondrial dysfunction in skeletal muscle. Clin Sci (Lond)

75. Martinelli M, Winterhalder R, Cerretelli P, Howald H, Hoppeler H (1990). Muscle lipofuscin content and satellite cell volume is increased after high altitude exposure in humans. Experientia 46:672-676

76. Mohanraj P, Merola AJ, Wright VP, Clanton TL (1998). Antioxidants protect rat diaphragmatic muscle function under hypoxic conditions. J Appl Physiol 84:1960-1966

77. Moller P, Loft S, Lundby C, Olsen NV (2001). Acute hypoxia and hypoxic exercise induce DNA strand breaks and oxidative DNA damage in humans. Faseb J 15:11811186

78. Monteiro P, Duarte AI, Moreno A, Goncalves LM, Providencia LA (2003). Carvedilol improves energy production during acute global myocardial ischaemia. Eur $J$ Pharmacol 482:245-253

79. Moore LG (2000). Comparative human ventilatory adaptation to high altitude. Respir Physiol 121:257-276

80. Nicolas M, Thullier-Lestienne F, Bouquet C, Gardette B, Gortan C, Joulia F, Bonnon M, Richalet JP, Therme P, Abraini JH (1999). An anxiety, personality and altitude symptomatology study during a 31-day period of hypoxia in a hypobaric chamber (experiment 'Everest-Comex 1997'). J Environ Psychol 19:407-414

81. Paradies G, Petrosillo G, Pistolese M, Di Venosa N, Federici A, Ruggiero FM (2004). Decrease in mitochondrial complex I activity in ischemic/reperfused rat heart: involvement of reactive oxygen species and cardiolipin. Circ Res 94:53-59

82. Paradies G, Petrosillo G, Pistolese M, Ruggiero FM (2000) The effect of reactive oxygen species generated from the mitochondrial electron transport chain on the cytochrome $c$ oxidase activity and on the cardiolipin content in bovine heart submitochondrial particles. FEBS Lett 466:323-326

83. Paradies G, Petrosillo G, Pistolese M, Ruggiero FM (2002). Reactive oxygen species affect mitochondrial electron transport complex I activity through oxidative cardiolipin damage. Gene 286:135-141

84. Park Y, Kanekal S, Kehrer JP (1991). Oxidative changes in hypoxic rat heart tissue. Am J Physiol 260:H1395-1405

85. Pearlstein DP, Ali MH, Mungai PT, Hynes KL, Gewertz BL, Schumacker PT (2002). Role of mitochondrial oxidant generation in endothelial cell responses to hypoxia. Arterioscler Thromb Vasc Biol 22:566-573

86. Petrosillo G, Ruggiero FM, Pistolese M, Paradies G (2001). Reactive oxygen species generated from the mitochondrial electron transport chain induce cytochrome $\mathrm{c}$ dissociation from beef-heart submitochondrial particles via cardiolipin peroxidation. Possible role in the apoptosis. FEBS Lett 509:435-438

87. Pfeiffer JM, Askew EW, Roberts DE, Wood SM, Benson JE, Johnson SC, Freedman MS (1999). Effect of antioxidant supplementation on urine and blood markers of oxidative stress during extended moderate-altitude training. Wilderness Environ Med 10:66-74

88. Powell SR, Gurzenda EM, Wahezi SE (2001). Actin is oxidized during myocardial ischemia. Free Radic Biol Med 30:1171-1176

89. Radak Z, Lee K, Choi W, Sunoo S, Kizaki T, Oh-ishi S, Suzuli K, Tanig (1994). Oxidative stress induced by intermittent exposure at a simulated altitude of $4000 \mathrm{~m}$ decreases mitochondrial superoxide dismutase content in soleus muscle of rats. Eur J.Appl Physiol 69:392-395

90. Richter C (1997). Reactive oxygen and nitrogen species regulate mitochondrial $\mathrm{Ca} 2+$ homeostasis and respiration. Biosci Rep 17:53-66

91. Risom L, Lundby C, Thomsen JJ, Mikkelsen L, Loft S, Friis G, Moller P (2007). Acute hypoxia and reoxygenationinduced DNA oxidation in human mononuclear blood cells. Mutat Res 625:125-133

92. Riva C, Chevrier C, Pasqual N, Saks V, Rossi A (2001). $\mathrm{Bcl}-2 / \mathrm{Bax}$ protein expression in heart, slow-twitch and fast-twitch muscles in young rats growing under chronic hypoxia conditions. Mol Cell Biochem 226:9-16

93. Rubin BB, Romaschin A, Walker PM, Gute DC, Korthuis RJ (1996). Mechanisms of postischemic injury in skeletal muscle: intervention strategies. J Appl Physiol 80:369-387

94. Rupert JL, Hochachka PW (2001). Genetic approaches to understanding human adaptation to altitude in the Andes. J Exp Biol 204:3151-3160

95. Samaja M (1997). Blood Gas Transport at High Altitude. Respiration:422-428

96. Santos DL, Moreno AJ, Leino RL, Froberg MK, Wallace KB (2002). Carvedilol protects against doxorubicin-induced mitochondrial cardiomyopathy. Toxicol Appl Pharmacol 185:218-227

97. Sarada SK, Dipti P, Anju B, Pauline T, Kain AK, Sairam M, Sharma SK, Ilavazhagan G, Kumar D, Selvamurthy W (2002). Antioxidant effect of beta-carotene on hypoxia induced oxidative stress in male albino rats. $J$ Ethnopharmacol 79:149-153

98. Sarada SK, Sairam M, Dipti P, Anju B, Pauline T, Kain AK, Sharma SK, Bagawat S, Ilavazhagan G, Kumar D (2002). Role of selenium in reducing hypoxia-induced oxidative stress: an in vivo study. Biomed Pharmacother 56:173-178 
99. Schild L, Huppelsberg J, Kahlert S, Keilhoff G, Reiser G (2003). Brain mitochondria are primed by moderate Ca2+ rise upon hypoxia/reoxygenation for functional breakdown and morphological disintegration. J Biol Chem 278:2545425460

100. Schild L, Reinheckel T, Reiser M, Horn TF, Wolf G, Augustin W (2003). Nitric oxide produced in rat liver mitochondria causes oxidative stress and impairment of respiration after transient hypoxia. Faseb J 17:2194-2201

101. Schlag MG, Harris KA, Potter RF (2001). Role of leukocyte accumulation and oxygen radicals in ischemia-reperfusioninduced injury in skeletal muscle. Am J Physiol Heart Circ Physiol 280:H1716-1721

102. Schmidt MC, Askew EW, Roberts DE, Prior RL, Ensign WY, Jr., Hesslink RE, Jr. (2002). Oxidative stress in humans training in a cold, moderate altitude environment and their response to a phytochemical antioxidant supplement. Wilderness Environ Med 13:94-105

103. Severinghaus JW (2000). Stumbling over a bias. What happens to spinal fluid $\mathrm{pH}$ at high altitude? Am J Respir Crit Care Med 161:3-4

104. Shroff EH, Snyder C, Chandel NS (2007). Bcl-2 family members regulate anoxia-induced cell death. Antioxid Redox Signal 9:1405-1409

105. Simon-Schnass I (2000). Risk of oxidative stress during exercise at high altitude. In: Sen CK, Packer L, Hannienen $\mathrm{O}$ (eds) Handbook of oxidants and antioxidants in exercise. Elsevier, Amsterdam, p 191-210

106. Singh SN, Vats P, Kumria MM, Ranganathan S, Shyam R, Arora MP, Jain CL, Sridharan K (2001). Effect of high altitude $(7,620 \mathrm{~m})$ exposure on glutathione and related metabolism in rats. Eur J Appl Physiol 84:233-237

107. Steiner DR, Gonzalez NC, Wood JG (2001). Leukotriene $\mathrm{B}(4)$ promotes reactive oxidant generation and leukocyte adherence during acute hypoxia. J Appl Physiol 91:11601167

108. Vanden Hoek TL, Becker LB, Shao Z, Li C, Schumacker PT (1998). Reactive oxygen species released from mitochondria during brief hypoxia induce preconditioning in cardiomyocytes. J Biol Chem 273:18092-18098

109. Vanden Hoek TL, Li C, Shao Z, Schumacker PT, Becker LB (1997). Significant levels of oxidants are generated by isolated cardiomyocytes during ischemia prior to reperfusion. J Mol Cell Cardiol 29:2571-2583

110. Vercesi AE, Kowaltowski AJ, Grijalba MT, Meinicke AR, Castilho RF (1997). The role of reactive oxygen species in mitochondrial permeability transition. Biosci Rep 17:43-52

111. Walker PM (1991). Ischemia/reperfusion injury in skeletal muscle. Ann Vasc Surg 5:399-402

112. Wallace KB, Eells JT, Madeira VM, Cortopassi G, Jones DP (1997). Mitochondria-mediated cell injury. Symposium overview. Fundam Appl Toxicol 38:23-37

113. Ward M, Milledge JS, West JB (2000). High Altitude Medicine and Physiology. New York: Oxford University Press Inc.

114. Webster KA (2007). Hypoxia: life on the edge. Antioxid Redox Signal 9:1303-1307

115. Wei YH, Lee HC (2002). Oxidative stress, mitochondrial DNA mutation, and impairment of antioxidant enzymes in aging. Exp Biol Med (Maywood) 227:671-682

116. West JB (1996). Prediction of barometric pressures at high altitude with the use of model atmospheres. J Appl Physiol

\section{$81: 1850-1854$}

117. West JB (1999). Barometric pressures on Mt. Everest: new data and physiological significance. J Appl Physiol 86:10621066

118. West JB (2003). Acclimatization to high altitude: truths and misconceptions. High Alt Med Biol 4:401-402

119. Westerterp KR, Meijer EP, Rubbens M, Robach P, Richalet JP (2000). Operation Everest III: energy and water balance. Pflugers Arch 439:483-488

120. Wood JG, Johnson JS, Mattioli LF, Gonzalez NC (1999). Systemic hypoxia promotes leukocyte-endothelial adherence via reactive oxidant generation. J Appl Physiol 87:1734-1740

121. Wood JG, Johnson JS, Mattioli LF, Gonzalez NC (2000). Systemic hypoxia increases leukocyte emigration and vascular permeability in conscious rats. J Appl Physiol 89:1561-1568

122. Wright VP, Klawitter PF, Iscru DF, Merola AJ, Clanton TL (2005). Superoxide scavengers augment contractile but not energetic responses to hypoxia in rat diaphragm. $J$ Appl Physiol 98:1753-1760

123. Xu XP, Pollock JS, Tanner MA, Myers PR (1995). Hypoxia activates nitric oxide synthase and stimulates nitric oxide production in porcine coronary resistance arteriolar endothelial cells. Cardiovasc Res 30:841-847

124. Yen HC, Oberley TD, Gairola CG, Szweda LI, St Clair DK (1999). Manganese superoxide dismutase protects mitochondrial complex I against adriamycin-induced cardiomyopathy in transgenic mice. Arch Biochem Biophys 362:59-66

125.Zamboni M, Armellini F, Turcato E, Robbi R, Micciolo R, Todesco T, Mandragona R, Angelini G, Bosello O (1996). Effect of altitude on body composition during mountaineering expeditions: interrelationships with changes in dietary habits. Ann Nutr Metab 40:315-324

126. Zhu WZ, Xie Y, Chen L, Yang HT, Zhou ZN (2006). Intermittent high altitude hypoxia inhibits opening of mitochondrial permeability transition pores against reperfusion injury. J Mol Cell Cardiol 40:96-106

127. Zuo L, Clanton TL (2005). Reactive oxygen species formation in the transition to hypoxia in skeletal muscle. Am J Physiol Cell Physiol 289:C207-C216 